\title{
Influencing Factors of Audit Report Lag: Evidence from Indonesia
}

\author{
Zaky Machmuddah ${ }^{\text {* }}$ \\ Adhin Fauziah Iriani ${ }^{1}$ \\ St. Dwiarso Utomo ${ }^{1}$ \\ ${ }^{1}$ Faculty of Economic and Business, \\ Universitas Dian Nuswantoro, Indonesia \\ ${ }^{*}$ Corresponding Author
}

DOI: https://doi.org/10.36941/ajis-2020-0119

\begin{abstract}
This study intends to reveal the influence of firm size, profitability, solvability, and size of the public accounting firm on audit report lag (ARL). The object of this research is mining firms listed on the Indonesia Stock Exchange (IDX) for the 2015-2018 period. Samples were chosen by purposive sampling method, uses secondary data with 96 samples, and applies multiple linear regression for data analysis. The finding of this research indicates that the solvability and size of public accounting firms influence the ARL. However, firms' size and profitability don't influence the ARL. The implication of the finding is issuers should pay attention to factors that affect ARL so that issuers are not subject to sanctions due to delays in the submission of audit reports from Financial Services Authority (OJK).
\end{abstract}

Keywords: firms size, profitability, solvability, size of the public accounting, audit report lag

\section{Introduction}

Publicly listed companies that are listed on the Indonesia Stock Exchange (IDX) must prepare and present financial reports under accounting standards to the public. Sanctions for non-compliance support the accounting standard rule. However, there are still companies that are suspended by the IDX every year because they are late in submitting their financial report. This phenomenon is the main issue in this research.

Ten issuers were temporarily suspended from trading their shares by the Indonesian Stock Exchange because the issuers had not submitted their interim financial reports for the period March 31, 2019, until the deadline of July 29, 2019. Besides, the suspension was also given because the issuers also had not paid payment fines for the delays. Quoted from cnbcindonesia.com, ten late issuers are PT. Golden Plantation, PT. Tiga Pilar Sejahtera Food, PT. Sugih Energy, PT. Borneo Lumbung Energy \& Metal, PT. Sigmagold Inti Perkasa, PT. Cakra Mineral, PT. Evergreen Invesco, PT. Apexindo Pratama Duta, PT. Nipress, PT. Bakrieland Development..

Financial reports are the final process of an accounting cycle in which there is information about evaluating a company's performance. For either going public company or not, financial reports are crucial. Therefore, financial reports must be appropriately made for it will affect the company's image, and also the decisions that will be taken by interested parties. 
One characteristic of financial reports is relevant. Relevant, defined as to be on time in the delivery. Public companies are required to submit their financial reports' audit no later than four months after the end of the financial year. As written in the Financial Services Authority (OJK) regulation number 29/POJK.04/2016, if the company is late in submitting its audit financial reports, it will be given administrative sanctions by the OJK.

The company expects to get a reasonable audit opinion. However, to convey these results, an auditor must examine each part of the firm's financial reports. When reviewing financial reports, an auditor must comply with the Professional Standards of Public Accountants. That is why completing an audit requires quite a long time. The difference in the date of the financial reports and issuance of the audit report shows the length of time the audit process. The phenomenon is called the Audit Report Lag (ARL). According to Al-Ghanem and Mohamed (2011), ARL is the time interval between the date of issuance of financial reports by companies and the date of issuance of audit reports by auditors. According to Hossain and Peter (1998), the longer the auditor in completing the audit work, the longer the ARL, and vice versa. ARL can occur due to several influencing factors. These factors come from within the company (internal) and come from outside the company (external) (Harjanto, 2017). Examples of internal factors are firms size, profitability, and solvability, while PAF's size is an external factor.

The firm's size is the size of the firms that can be measured through the firm's total assets. Research from Modugu et al. (2012) stated that the number of assets could represent how much wealth is owned by the firms. The firm's size has a relationship to audit delay because the larger the firms, the better the internal control system (Fodio, et al., 2015) and is monitored closely by interested parties (Dyer \& Mc. Hugh, 1975). According to research by Wijayanti, et al. (2019), Adinata (2019), Saleh, et al. (2019), Hassan (2016), Modugu et al. (2012), Al-Ghanem and Mohamed (2011), and Khasharmeh and Khaled (2010), firms size influences ARL. However, according Fadrul \& Astuti (2019), Tannuka (2018), Yendrawati \& Mahendra (2018), and Ayemere and Afensimi, (2015) firms size does not influence ARL.

Besides firms size, another factor that might influence ARL is profitability. Profitability is defined as the capability of firms to generate profits. Profitability is measured through the firm's income statement because it can show the performance of a firm. Apadore and Marjan (2013) stated that companies that capable of obtaining profitability would tend to publish their financial reports more quickly; it is a good signal for their users to make decisions. Based on research by Wijayanti, et al. (2019), Abbas, et al. (2019), Adinata (2019), Saleh, et al. (2019), Tannuka (2018), Yendrawati \& Mahendra (2018), Ayemere and Marjan (2015), Vuko (2014), Apadore (2013), Alkhatib and Qais (2012), Khasharmeh and Khaled (2010) profitability influences ARL. On the other hand, research from Chasanah \& Sagoro (2017) and Modugu et al. (2012), proving that profitability does not influence ARL.

Another factor causing the ARL is solvability. Solvability is a firm's ability to pay off its debts, both long-term and short-term debt (Chasanah \& Sagoro, 2017). Research from Abbas et al. (2019) proves that solvability influences ARL. If the amount of debt owed by the firms is high, it causes the audit process to be relatively long because the auditor needs to be careful since it involves the survival of the firms. The results of those studies differ from Saleh et al. (2019), Tannuka (2019), Yendrawati \& Mahendra (2018), Chasanah \& Sagoro (2017) which that solvability does not influence ARL. Auditors assume that total debt, either large or small, on the firms, has no difference.

Furthermore, another factor that can influence ARL is the size of public accounting firms. Companies that choose to use excellent PAF services will be able to improve the quality of financial reports. Big Four accounting firms are well-affiliated KAP. The audit firm with extensive human resources is better than those of the audit firms that are classified as small; therefore, it will accelerate the completion of its audit work (Modugu et al., 2012). In line with research from Adinata (2019), Tannuka (2018) which stated that PAF's size influence ARL, but research from Fadrul \& Astuti (2019), Yendrawati \& Mahendra (2018), Susianto (2017), PAF's size does not influence ARL.

Research findings are still varied, so it is worthy of review. Mining companies listed on the IDX are the object of research because this sector has problems regarding the delay in the submission of financial reports during the study period. The observation period took place in $2015-2018$ because the data is the latest data on the IDX. Therefore, hopefully, the results are expected to be relevant to the 
current conditions. At least, the research question is: does firms size, profitability, solvability, PAF's size influence ARL in mining sector companies listed on the IDX for the 2015-2018 period?

\section{Literature Review}

\subsection{Compliance Theory}

Compliance theory is a theory which states that every firm must obey the rules because the legal drafting authority has the right to dictate behavior (normative commitment through legitimacy). According to Sutinen \& Kuperan (1999), from the perspective of economics, compliance theory has many neoclassical perspectives in looking at the rules in the business world is an obstacle in getting the maximum business profitability. Compliance theory has been investigated in the social sciences, especially in the fields of sociology and psychology, that focus more on the need for socialization processes in influencing an individual's compliance behavior. Compliance theory is divided into two perspectives, namely the instrumental and normative. The instrumental perspective is individuals who are entirely motivated by personal interests and responses to changes in incentives, while normative perspective is who deals with morals and contradict personal interests.

Based on a normative perspective, compliance theory should be applied in the field of accounting. POJK No. 29/POJK.04/2016 mentioned that each issuer is required to comply with the provisions in the legislation and, in particular, in the timely delivery of financial reports to the OJK. It can be concluded that the compliance of the issuer or public company in reporting or submitting financial reports is essential to fulfilling the compliance principle of timely disclosure of information. Issuers who violate one of the regulations will be subjected to administrative sanctions in the form of written warnings, fines, restrictions on business activities, freezing of business activities, revocation of business licenses, cancellation of approval and cancellation of registration.

\subsection{Signaling Theory}

According to Brigham \& Houston (2014), a signal is an action taken by a firm to guide investors about how management views the firm's prospects. The signal given is in the form of performance information that has been carried out by management to realize the owner's expectations. Generally, managers have the motivation to convey proper information about the company's performance to the public as quickly as possible. If the signals given by managers can convince the public, then the public will be impressed, which is reflected in the stock price. However, if financial information provides a bad rating, it can affect trading decisions and stock prices as well. The information signal is needed by investors to consider and determine whether to invest their shares or not in the company concerned.

\subsection{Hypothesis Development}

\subsubsection{The Influence of Firms Size on ARL}

Large companies tend to report their financial reports faster than smaller companies. According to Ariani \& Bawono (2018), firms size is a pace function of financial statements publication because large-size companies have proper internal controls that encourage auditors to complete the audit process promptly.

The firm's size can also give signals to external parties as a form of evaluating a firm's performance because when a firm's performance increases, managers will be motivated to announce this good information to the public. Wijayanti et al. (2019), Adinata (2019), Saleh, et al. (2019), Ariani \& Bawono (2018), Chasanah \& Sagoro (2017), Susianto (2017), Hassan, (2016), Modugu et al., (2012), Al-Ghanem and Mohamed, (2011), and Khasharmeh and Khaled, (2010) supports this hypothesis. Based on the description and findings of the research, the hypothesis taken is

H1: Firms size influences ARL. 


\subsubsection{The Influence of Profitability on ARL}

Profitability is proof of the firm's success in making a profit. The level of profitability will influence the duration of the ARL. High profitability indicates the success of firms in generating earnings because it is a signal in the form of good new information for a firm. A company that has succeeded in increasing its profitability is likely to be faster in its audit process because the company wants to immediately convey a signal (good information) to the public and interested parties. The relationship between the theory of compliance with profitability is that if profitability is high, the possibility of late submission of financial reports is slight because the auditor does not need a longer time in completing the audit so that the company can submit financial statements promptly.

In a study conducted by Wijayanti et al. (2019), it was found that the profitability variable influenced ARL. The results of the study are inline as those of Abbas, et al. (2019), Adinata (2019), Saleh, et al. (2019), Tannuka (2018), Yendrawati \& Mahendra, (2018), Ayemere and Marjan, (2015), Vuko, (2014), Apadore, (2013), Alkhatib and Qais, (2012), Khasharmeh and Khaled, (2010). By the results outlined above, the second hypothesis formed is

$\mathrm{H}_{2}$ : Profitability influences ARL.

\subsubsection{The Influence of Solvability on ARL}

The firm's solvability represents the firm's ability to meet its long-term obligations. The high amount of debt causes the auditor to be more careful when conducting the audit process because it involves the survival of the company. Therefore, the possibility of ARL will be longer and also late in announcing financial reports promptly. The high solvability of the company can also give a bad signal to investors, resulting in a decline in the firm's stock price. This research was supported by Abbas et al. (2019) and Sastrawan \& Latrini (2016), which stated that solvability influences ARL. By the description above, the third hypothesis proposed is

$\mathrm{H}_{3}$ : Solvability influences ARL.

\subsubsection{The Influence of Public Accounting Firm's Size on ARL}

A reputable PAF can conduct an audit process more efficiently and effectively in completing the audit on schedule, so users of financial reports more quickly accept that information. Companies that use the Big-Four PAF will finish their audit report faster than non-big four PAF. The reputation of the BigFour PAF, resulting in better audit quality than non-Big Four PAF. Therefore, the company can report its financial reports promptly and give a good signal to the public. This research is supported by Adinata (2019) and Tannuka (2018), which stated that the public accounting firm's size influences the ARL. Based on the description above, the final hypothesis proposed is

$\mathrm{H}_{4}$ : The size of a public accounting firm influences ARL.

\section{Research Method}

The population in this research was mining sector companies listed on the IDX for the 2015-2018 period. Furthermore, to obtain samples under specified criteria, this research used a purposive sampling method. Some criteria determined by researchers are mining sector companies that provide data on financial reports for the 2015-2018 period, companies that publish financial statements have suffered losses.

The dependent variable in this study is the ARL, which can be measured quantitatively in several days. The formula follows equation 1 (Harjanto, 2017). The independent variables used in this study are firm size, profitability, solvability, and size of the public accounting firm. The firm's size is the size of the company, which is valued by the total assets of the company-the formula of company size as equation 2 (Harjanto, 2017). Profitability is calculated using profit margins as equation 3 (Brigham \& Houston, 2018). Solvability is computed using the debt to equity ratio formula (see equation 4 ), which 
provides an overview of the company's capital structure. So, the level of risk of uncollectible liability is visible, with the following formula (Darminto, 2015).

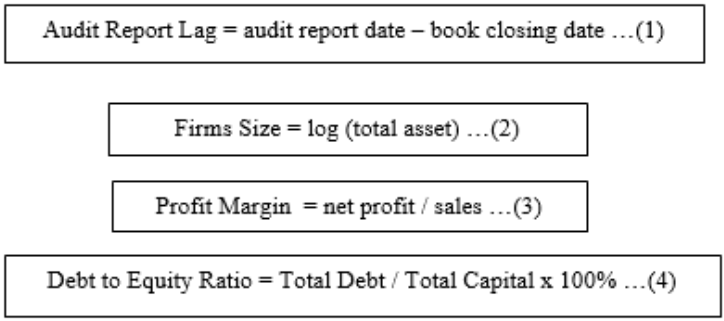

According to Harjanto (2017), the size of a public accounting firm is categorized as follows: a) if the company uses the services of a public accounting firm that works with the big-four, the code is 1 ; b) if the firm does not use the services of a public accounting firm that works with big four, the code is 0 .

\subsection{Analysis Tool}

The multiple regression analysis methods were used to determine the influence of the independent variable on the dependent variable. In this analysis method, the independent variable influences the dependent variable. Regression models used by researchers follow equation 5 .

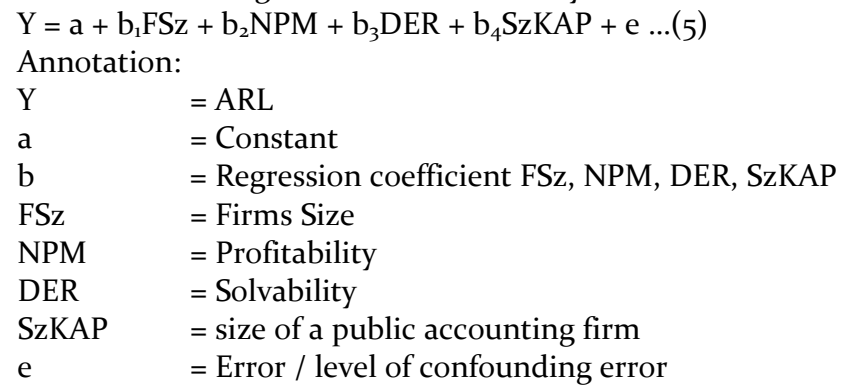

\section{Result and Discussion}

The population in this research is mining sector companies listed on the IDX for the period 2015 - 2018. There were 50 mining companies listed on the IDX until the end of 2018. In this study, the sample selection used the purposive sampling method, the criteria used to choose samples, among others:

Table 1. Research Sample

\begin{tabular}{|c|c|c|c|c|c|}
\hline \multirow{2}{*}{ Description } & \multicolumn{4}{|l|}{ Year } & \multirow[b]{2}{*}{ Total } \\
\hline & 2015 & 2016 & 2017 & 2018 & \\
\hline Mining companies listed on the IDX during the study period & 50 & 50 & 50 & 50 & 200 \\
\hline \multicolumn{6}{|l|}{ Criteria: } \\
\hline 1. Mining companies do not provide financial reports data. & $(11)$ & $(6)$ & (3) & $(5)$ & $(25)$ \\
\hline $\begin{array}{l}\text { 2. Mining companies do not issue financial reports that have been audited by an } \\
\text { independent auditor. }\end{array}$ & - & $(1)$ & - & - & $(1)$ \\
\hline 3. Mining companies suffer losses. & $(21)$ & $(18)$ & (9) & (10) & $(58)$ \\
\hline Total sample & 18 & 25 & 38 & 35 & 116 \\
\hline
\end{tabular}

Source: IDX data that has been processed by the author 
Based on the data observed, in detail, the number of mining sector companies listed on the IDX and have the required data in this study were 116 companies. In 2015, 18 companies met the criteria; in 2016, there were 25 companies, in 2017 , there were 38 companies, and in 2018 , there were 35 companies. The data used in this study are companies listed on the Stock Exchange in 2015-2018. The samples of this study were 116 data, but not normally distributed. Therefore, 20 data outliers were carried out, 96 of them were the research samples.

\subsection{Multiple Linear Regression Analysis}

The purpose of a multiple linear regression test is to figure out the magnitude of the influence of the independent variable with the dependent variable. Based on SPSS calculations, simple linear regression shows the results in the Table 2.

Table 2. Regression Model Testing Results

\begin{tabular}{|c|c|c|c|}
\hline \multirow{2}{*}{\multicolumn{2}{|c|}{ Model }} & \multicolumn{2}{|c|}{ Unstandardized Coefficients } \\
\hline & & B & Std. Error \\
\hline \multirow{5}{*}{1} & (Constant) & 77,118 & 36,839 \\
\hline & $\mathrm{FSz}$ & $-0,286$ & 2,951 \\
\hline & NPM & 0,164 & 0,221 \\
\hline & DER & 1,202 & 0,678 \\
\hline & SzKAP & $-10,865$ & 3,772 \\
\hline
\end{tabular}

Source: Processed secondary data, 2020

Based on Table 2 above, the multiple linear regression equation is obtained as equation (6)

$\mathrm{ARL}=77,118-0,286(\mathrm{FSz})+$ 0,164 (NPM) + 1,202 (DER) - 10,865 (SzKap) + e ... (6)

The coefficient of determination shows the magnitude of the ability of independent variables in explaining the variation of the dependent variable. Thus, in this study, the importance of the ability of firms size, profitability, solvability, and PAF's size explains the variation of ARL. The test results obtained can be seen in the adjusted $\mathrm{R}$ square Table 3. In Table 3, it can be seen that the adjusted $\mathrm{R}$ square $\left(\mathrm{R}^{2}\right)$ value is 0.116 . Thus, it can be concluded that firms size, profitability, solvability, and PAF's size (independent variables) in this study are explaining ARL (dependent variable) by $11.6 \%$, while the remaining $88.4 \%$ explained by other factors not included in this research model.

Table 3. $\mathrm{R}^{2}$ Test

\begin{tabular}{|c|c|c|c|}
\hline Model & R & R Square & Adjusted R Square \\
\hline 1 & $0,391^{\text {a }}$ & 0,153 & 0,116 \\
\hline
\end{tabular}

a. Predictors: (Constant), SzKAP, DER, NPM, FSz

b. Dependent Variable: ARL

c. Source: Processed secondary data, 2020

F test was conducted to find out whether all of the independent variables have a joint influence on the dependent variable. It is known by observing the significance value; the hypothesis is accepted if the sig value. $<0.05$ and sig. $<0.10$; F test results can be seen in Table 4 . After processed, Table 4 shows the results of $\mathrm{F}=4.104$ with a significant value of $0.004<0.05$, the significant value obtained is $<0.05$. Therefore, it can be concluded that firm's size, profitability, solvability, and PAF's size have a mutual influence on ARL. 
Table 4. F Test

\begin{tabular}{|l|l|c|c|c|c|c|}
\hline Model & Sum of Squares & df & Mean Square & F & Sig. \\
\hline & Regression & 4105,751 & 4 & 1026,438 & 4,104 &, $004^{\mathrm{b}}$ \\
\hline
\end{tabular}

a. Dependent variables: ARL

b. Predictors: (Constant), SzKAP, DER, NPM, FSz

c. Source: Processed secondary data, 2020

T-test was conducted to determine the magnitude of the independent variable in explaining the variation of the dependent variable. To find out, the following provisions are used: the hypothesis can be accepted if the value of sig. <0.05. Hypothesis testing results can be seen in Table 5 . The results of the research that have been obtained, ARL (dependent variable) can be explained by firms size, profitability, solvability, and PAF's size simultaneously (independent variables) can be accepted. Partially, firms size does not influence ARL, which means that firms' size will not influence the firm's delay in reporting their annual financial reports.

Furthermore, profitability does not influence ARL, which means the profit of the mining firms in this study does not influence the firm's delay in annual financial reporting. However, solvability partially affects ARL, which means that the debt size owned by mining companies in this study influences delays in annual financial reporting. PAF's size influences ARL, which means that in carrying out the audit process, PAF's size can cause delays in financial reporting in this study.

Table 5. T-test

\begin{tabular}{|l|l|c|c|}
\hline \multicolumn{2}{|c|}{ Model } & T & Sig. \\
\hline \multirow{4}{*}{1} & (Constant) & 2,093 & 0,039 \\
\cline { 2 - 4 } & FSz & $-0,097$ & 0,923 \\
\cline { 2 - 4 } & NPM & 0,741 & 0,461 \\
\cline { 2 - 4 } & DER & 1,774 & 0,079 \\
\cline { 2 - 4 } & Sz_KAP & $-2,881$ & 0,005 \\
\hline
\end{tabular}

a. Dependent variable: ARL

b. Source: Processed secondary data, 2020

\subsection{Discusssion}

\subsubsection{The Influence of Firms Size on ARL}

The result of hypothesis testing indicates a significance value of 0.923 is higher than 0.05 . Thus the hypothesis is rejected. The result shows that firms size does not influence ARL. The firm's size is the size that can be calculated from the number of assets owned. The more assets held by the firms, the more likely it is to be categorized in large companies. The higher the size of a firm, the better the internal control; to shorten the auditor's time in completing the audit process.

In this study, the firm's size does not influence ARL, which means firms' size does not affect the time of completion of the audit report. Therefore, the theories and hypotheses that were formed earlier were not accepted since the firms have contracted an independent competent auditor to audit the firm's financial reports (Fadrul and Sherly, 2019). This result was supported by the results of research conducted by Wijayanti et al. (2019), Fadrul \& Astuti (2019), Tannuka (2018), Yendrawati \& Mahendra (2018), and Ayemere and Afensimi, (2015) which states that firms size does not affect ARL.

\subsubsection{The Influence of Profitability on ARL}

The hypothesis test result indicates that the probability value of 0.461 is higher than 0.05 . Thus the hypothesis is rejected. The results show that profitability does not affect ARL. Companies that have high profitability value indicate the success of firms in generating profits. The relationship between the 
compliance theory with profitability is that, if profitability is high, the possibility of late submission of financial reports is low. The auditor does not need a long time to complete the audit and the regulations governing the limits of the published financial statement so that the firms can submit financial reports promptly. The regulation is written in OJK regulation number 29/POJK.04/2016. The result of this research is in line with Wijayanti et al. (2019), Saleh, et al. (2019), Chasanah \& Sagoro (2017), Harjanto (2017), and Modugu et al. (2012), which states that the profitability does not influence ARL.

\subsubsection{The Influence of Solvability on ARL}

Hypothesis test results show a probability value of 0.079 is smaller than 0.10 . Thus the hypothesis is accepted. The test result indicates that solvability influences audit lag report. Solvability is a firm's ability to pay off its debts. The high amount of debt causing the auditor more careful when conducting the audit process because it involves the firm's survival. Therefore, the possibility of ARL will be longer and will late in announcing financial reports promptly. The high solvability of the firms can also give a wrong signal to investors, resulting in a decline in the firm's stock price. Abbas supports the findings of this study, et al. (2019) and Sastrawan \& Latrini (2016), which prove that solvability influences ARL.

\subsubsection{The Influence of Public Accounting Firm's Size on ARL}

The result of hypothesis testing in this study indicates that the probability value of 0.005 is smaller than 0.05 . Thus the last hypothesis was accepted. The test results show that the PAF's size influences the ARL. Its affiliation categorizes PAF's size, whether it is included in Big Four or Non-Big Four. According to Tannuka (2018), large PAF will have a relatively faster time in completing the audit process. The condition because large PAF generally has more significant resources in terms of competence, expertise, and ability of auditors compared to smaller PAF so that the process of completing audit work will be more effective and efficient.

Through the results of this hypothesis testing, it can be concluded that PAF's size can determine a significant influence time of the audit works. In this study, PAF's size influences ARL, which means that the larger the PAF's size, the shorter the ARL. This result is in line with the compliance theory previously explained, where firms and PAF must comply with applicable regulations so that they do not get sanctions for delays in submitting financial reports. Therefore, the firms can report their financial report promptly and give a good signal to the public. The Big Four PAF is believed to have good audit quality because of experience in auditing worldwide so that it can complete the audit process effectively and efficiently. The results of this study are in line with research by Adinata (2019), Tannuka (2018), which shows that PAF's size influences ARL.

\section{Conclusion}

The results of the study can be concluded as follows: solvability and PAF's size influence ARL on mining companies listed on the IDX in the 2015-2018 period. However, firms' size and profitability have no influence on ARL on mining companies listed on the IDX in the 2015-2018 period. Limitations of this study are the ability to analyze and process data that can be seen in the coefficient of determination, only limited to $11.6 \%$ of the four independent variables. The remaining $88.4 \%$ is explained by other factors which not tested in this study. Following the research results that have been conducted, further research expected to be able to accomplish this research by adding other variables which not examined by the researcher such as the current year's profit/loss, liquidity, the influence of IFRS mandatory implementation, audit opinion, subsidiaries, committees audit, and others variables. The implication of the results is issuers should pay attention to factors that affect ARL so that issuers are not subject to sanctions due to delays in the submission of audit reports from OJK. 


\section{References}

Abbas, D. S., Hakim, M. Z., \& Rustandi, R. (2019). The Influence of Profitability, Solvency, Audit Opinion and Reputation of Public Accounting Firms on Audit Lag Report (On Manufacturing Companies Listed on the Indonesia Stock Exchange in 2012-2015). Competitive, Vol. 3 (1), 20-39.

Al-Ghanem, W. and Mohamed, H. (2011). An Empirical Analysis of Audit Delays and Timeliness of Corporate Financial Reporting in Kuwait. Eurasian Business Review. Vol.1, 73-90.

Alkhatib, K. and Qais, M. (2012). Audit Report Timelines: Empirical Evidence from Jordan. Social and Behavioral Sciences. 1342-1349.

Apadore, K. and Marjan, M. N. (2013). Determinant audit lag and corporate governence in Malaysia. Internasional Journal of Busines and Management, Vol. 8(15).

Ariani, K. R., \& Bawono, A. D. B. (2018). The Effect of Company Size and Age on Audit Lag Report with Profitability and Solvency as Moderating Variables. Indonesian Accounting and Financial Research, Vol. 3(2), 118-126.

Ayemere, I. L. and Afensimi, E. (2015). Corporate Attributes and Audit Delay in Emerging Markets: Empirical Evidence from Nigeria. International Journal of Business and Social Research, Vol.5 (3).

Brigham, E. F., \& Houston, J. F. (2018). Fundamentals of Financial Management (11th ed.).

Chasanah, I. U., \& Sagoro, E. M. (2017). Factors that Influence Audit Lag Report on LQ-45 Companies. Profita Study of accounting. Vol. 5 (4), 1-21.

Dyre, J. C. and McHugh, A. L. (1975). The Timeliness of The Australian Annual Report. Journal of Accounting Research. Vol. 13 (3), 204-219.

Fadio, M. I., Victor, C. O., Abiodan, B. O. and Ahmed, A. Z. (2015). IFRS Adoption, Firm Traits and Audit Timeliness: Evidence From Nigeria. Journal Acta Universitatis Danubius. Vol. 11 (3), 126-139.

Fadrul, \& Astuti, S. (2019). Analysis of Factors Affecting the Audit Lag Report on Chemical Sub Sector Manufacturing Companies Listed on the Indonesia Stock Exchange (IDX) 2013-2017. Bilancia, Vol. 3(1), 45-56.

Harjanto, K. (2017). Effect of Company Size, Profitability, Solvency, and Size of Public Accounting Firms on Audit Delay. ULTIMA Accounting Journal, Vol. 9(2), 33-49.

Hassan, Y. M. (2016). Determinant of Audit Report-Lag: Evidence Palestina. Journal of Accounting In Emerging Economies, Vol.6.1.

Hossain, M. A. and Peter, J. T. (1998). An Examination of Audit Delay: Evidence From Pakistan. Papers by for APIRA 98 in Osaka. 1-16.

Khasharmeh, H. A. and Khaled, A. (2010). The Timelines of Annual Report in Bahrain and The United Arab Emirate: An Empirical Comparative Study. The International Jurnal of Busines and Finance Ressearch, Vol.4.

Modugu, P. K., Emmanuel, E. and Ohiorenuan, J. I. (2012). Determinants of Audit Delay in Nigerian Companies: Empirical Evidence. Research Journal of Finance and Accounting. Vol. 3, No. 6, 46-54.

Saleh, A. N. S., \& Afifudin. (2019). Factors Affecting Audit Lag Report (Empirical Study of Manufacturing Companies Listed on the Indonesia Stock Exchange in 2016-2018). E-JRA Vol. o8(10), 116-130.

Sastrawan, I. P., \& Latrini, M. Y. (2016). The Effect of Profitability, Solvency, and Company Size on Audit Lag Report on Manufacturing Companies. E-Journal of Accounting, Vol. 17(1), 311-337.

Susianto, S. N. (2017). Effect of IFRS Obligatory Application, Industry Type, Loss, Subsidiaries, KAP Size, Company Size, Audit Opinion, and Audit Committee Size on Audit Report Lag (ARL) (Empirical Study of Companies Listed on the Indonesia Stock Exchange for the 2009-2013 Period). Journal of Environmental Management, Vol. 211(1), 247-255.

Sutinen, J. G., \& Kuperan, K. (1999). A socio- economic theory of regulatory compliance. International journal of social economics, 174-193.

Tannuka, S. (2018). Effect of Company Size, Profitability, Solvency, Liquidity, and Cap Size on Audit Lag Report (Empirical Study on Property, Real Estate, and Building Construction Companies Listed on the Indonesia Stock Exchange for the 2011-2015 Period). Muara Journal of Economics and Business, Vol. 2(2), 353.

Vuko, T. and Marko, C. (2014). Finding determinants of audit delay by pooled OLS regression analysis. Croatian Operational Research Review. Vol.5, 81-91.

Wijayanti, Y. P., Machmuddah, Z., Utomo, S.D. (2019). Audit Delay: Case Studies at Conventional Bank in Indonesia. Journal of Innovation in Business and Economics. Vol.3(1), 33-40.

Yendrawati, R., \& Mahendra, V. W. (2018). The Influence of Profitability, Solvability, Liquidity, Company Size and Size of Public Accountant Firm on Audit Report Lag. The International Journal of Social Sciences and Humanities Invention, 5(12), 5170-5178. 